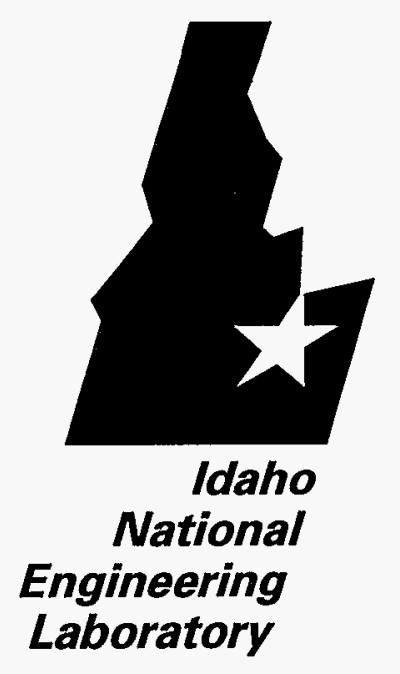

INEL-95/0291

$$
\begin{aligned}
& \text { OCT } 211995 \\
& \text { OSTI }
\end{aligned}
$$

June 1995

\title{
Waste Streams that Preferentially Corrode 55-gallon Steel Storage Drums
}

Larry R. Zirker

George A. Beitel

Curtis M. Reece 
This report was prepared as an account of work sponsored by an agency of the United States Government. Neither the United States Government nor any agency thereof, nor any of their employees, makes any warranty, express or implied, or assumes any legal liability or responsibility for the accuracy, completeness, or usefulness of any information, apparatus, product, or process disclosed, or represents that its use would not infringe privately owned rights. Reference herein to any specific commercial product, process, or service by trade name, trademark, manufacturer, or otherwise does not necessarily constitute or imply its endorsement, recommendation, or favoring by the United States Government or any agency thereof. The views and opinions of authors expressed herein do not necessarily state or reflect those of the United States Government or any agency thereof.

\title{
Waste Streams that Preferentially Corrode 55-gallon Steel Storage Drums
}

Larry R. Zirker

George A. Beitel

Curtis M. Reece

Published June 1995

\section{Idaho National Engineering Laboratory Lockheed Martin Idaho Technologies Idaho Falls, Idaho 83415}

\author{
Prepared for the \\ U.S. Department of Energy \\ Assistant Secretary for Environmental Management \\ Under DOE Idaho Operations Office \\ Contract DE-AC07-94ID13223
}




\section{DISCLAMMER}

Portions of this document may be illegible in electronic image products. Images are produced from the best available original document. 
Waste Streams that Preferentially Corrode 55-gallon Steel Storage Drums
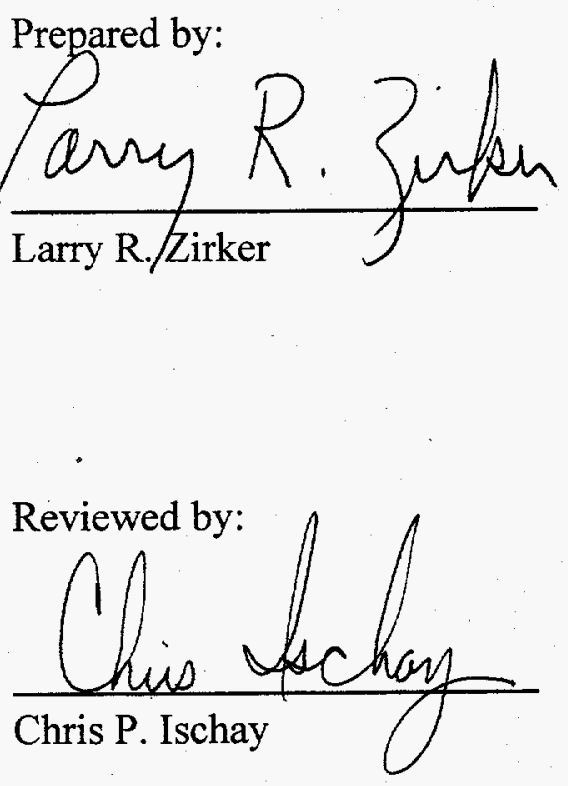

Approved by:

Longe a. Betel

George A. Beitel $\frac{6 / 14 / 95}{\text { Date }}$

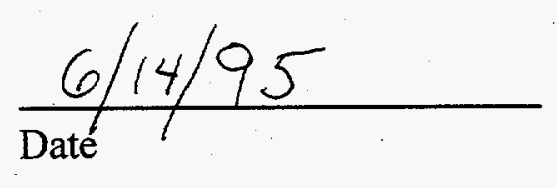

$\frac{6 / 15 / 95}{\text { Date }}$

iii 


\section{ABSTRACT}

When 55-gal steel drum waste containers fail in service, i.e., leak, corrode or breach, the standard fix has been to overpack the drum. When a drum fails and is overpacked into an 83-gal overpack drum, there are several negative consequences:

- waste generation due to the $50 \%$ increase (from 55 -gals to 83 -gals) of disposable volume

- $\quad$ loss of limited storage or disposal space

- $\quad$ increased disposal costs

- increased cost for the overpack drum

- increased labor, handling, and management costs.

Identifying waste streams that preferentially corrode steel drums is essential to the pollution prevention philosophy that "an ounce of prevention is worth a pound of cure." It is essential that facilities perform pollution prevention measures at the front end of processes to reduce pollution on the back end. If these waste streams can be identified before they are packaged, the initial drum packaging system could be fortified or increased to eliminate future drum failures, breaches, clean-ups, and the plethora of other consequences.

Therefore, a survey was conducted throughout the U. S. Department of Energy complex for information concerning waste streams that have demonstrated preferential corrosion of 55-gal steel drums. From 21 site contacts, 21 waste streams were so identified. The major components of these waste streams include acids, salts, and solvent liquids, sludges, and still bottoms. The solvent-based waste streams typically had the shortest time to failure, 0.5 to 2 years.

This report provides the results of this survey and research. 


\section{CONTENTS}

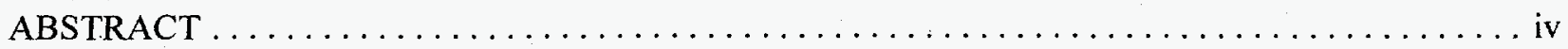

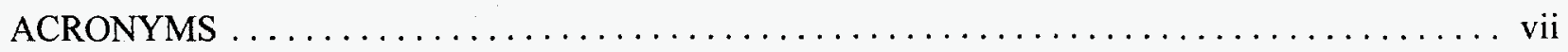

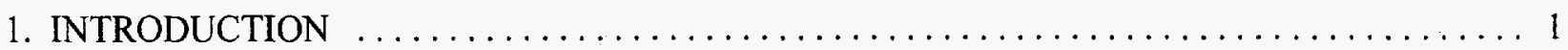

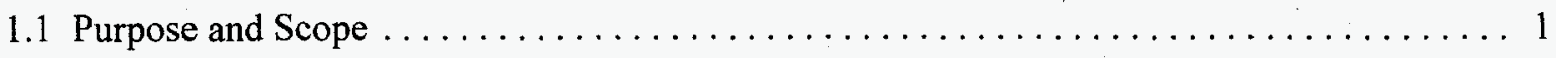

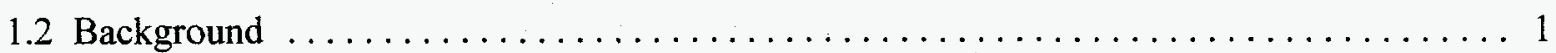

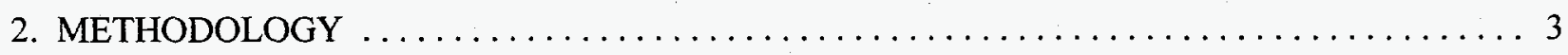

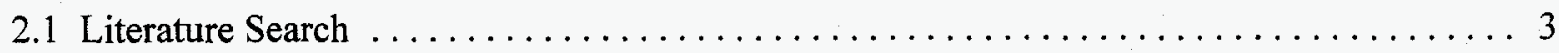

2.2 Idaho National Engineering Laboratory $\ldots \ldots \ldots \ldots \ldots \ldots \ldots \ldots \ldots \ldots \ldots \ldots \ldots \ldots \ldots \ldots$

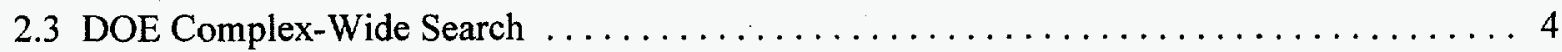

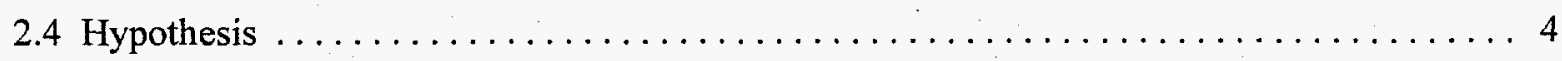

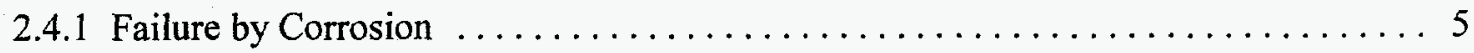

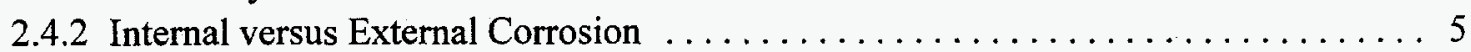

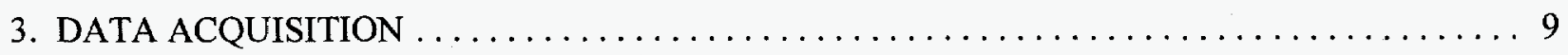

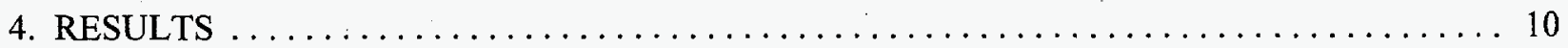

5. RECOMMENDATIONS AND CONCLUSIONS $\ldots \ldots \ldots \ldots \ldots \ldots \ldots \ldots \ldots \ldots \ldots \ldots \ldots \ldots \ldots \ldots \ldots$

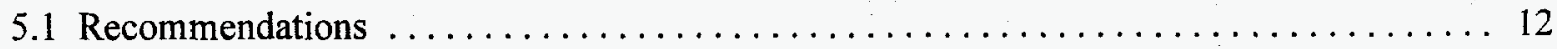

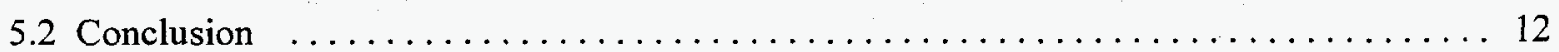

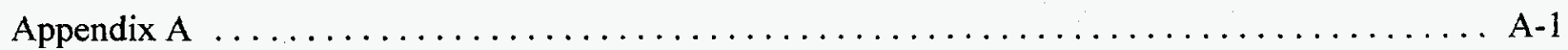

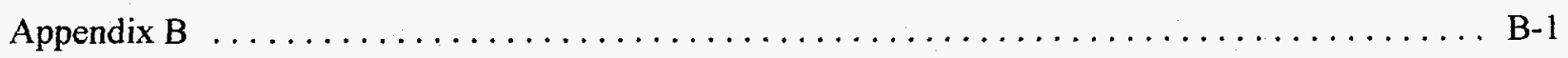

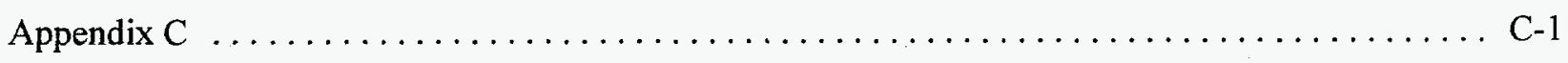

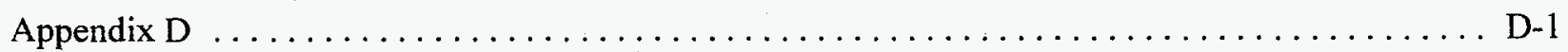




\section{FIGURES}

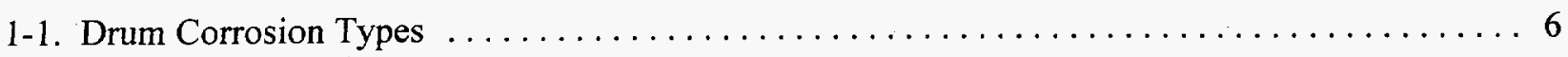

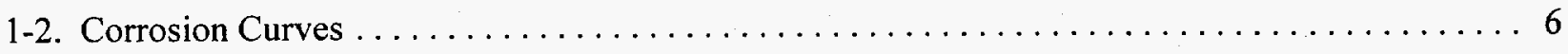

2. Expected Drum Failure Rates $\ldots \ldots \ldots \ldots \ldots \ldots \ldots \ldots \ldots \ldots \ldots \ldots \ldots \ldots \ldots \ldots \ldots$

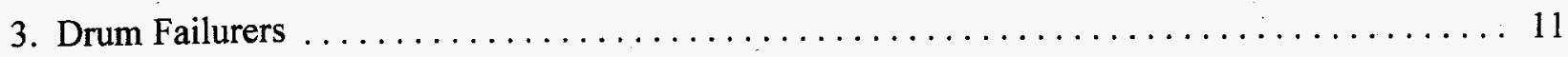




\section{ACRONYMS}

DOE-HQ Department of Energy Headquarters

INEL

Idaho National Engineering Laboratory

MWSF

$\mathrm{P}^{2}$

Mixed Waste Storage Facility

RWMC

Pollution Prevention

TCA

Radioactive Waste Management Complex

WROC

trichloroethane

WS

Waste Reduction Operations Complex

Waste Stream 


\section{Waste Streams that Preferentially Corrode 55-gallon Steel Storage Drums}

\section{INTRODUCTION}

\subsection{Purpose and Scope}

The purpose of this project was to identify the waste streams within the DOE complex that have demonstrated preferential corrosion on 55-gal steel drums while stored at various DOE sites. This work was performed by the Lockheed Martin Idaho Technology Pollution Prevention Special Projects. The results of that survey are discussed in this report.

A survey was conducted throughout the U. S. Department of Energy complex for information concerning waste streams that have demonstrated preferential corrosion to 55-gal steel drums. The initial search was conducted at the Idaho National Engineering Laboratory's Mixed Waste Storage Facility (MWSF). DOE-HQ later requested that the data search be expanded complex wide. This report is the culmination of the efforts to identify these waste streams.

\subsection{Background}

Several low-level mixed waste drums containing nitric acid solution which was used to remove contaminated mercury residues are stored at the MWSF at the Idaho National Engineering Laboratory (INEL). This mercury sludge waste stream has been observed to be especially corrosive to 55-gal steel storage drums. Over the last few years, all drums of this waste stream have been overpacked into 83-gal polyethylene (poly) drums because the sludge de-waters, and the liquid corrodes (via pitting corrosion) the original drums from the inside out until leaks occurred.

As a result of investigating this corrosion problem, the author met with the INEL Container Integrity Committee, which was established to study storage container corrosion problems. After meeting with the committee and discussing the corrosion problems at the INEL, it was obvious that the drum management process at the INEL had a high potential for pollution prevention $\left(\mathrm{P}^{2}\right)$ and waste minimization opportunities.

When a drum fails in service at the INEL, it is overpacked in a standard waste box or in an 83-gal (steel or poly) overpack drum (85-gal steel, poly, or stainless steel drums are used at some sites as overpacks). When a drum is overpacked there are several consequences:

- waste generation directly measurable due to the $50 \%$ increase (from 55 -gals to 83 -gals) of disposable volume

- a loss of the limited storage/disposal space 
- increase of disposal costs

- $\quad$ cost for the overpack drum

- labor, handling, and management costs.

Identifying waste streams that are especially corrosive to steel drums is essential for $\mathrm{P}^{2}$. Since an integral part of the $\mathrm{P}^{2}$ philosophy is "an ounce of prevention is worth a pound of cure," it is essential that $\mathrm{P}^{2}$ measures be performed at the front end of the process.

If these waste streams can be identified before they are packaged, the initial drum could be fortified to eliminate future drum failures, breaches, clean-ups, and the previously listed consequences. It is not always intuitively obvious which waste stream will exhibit the most corrosive behavior on the steel drum material, or what the synergistic interactions between the chemicals, cement, and the drum will be. However this study did find and identify many of these corrosive waste streams for future reference. 


\section{METHODOLOGY}

\subsection{Literature Search}

An extensive literature search of published data was performed. With the computerized data bases available, a comprehensive literature search was quickly completed. Key words used included:

$\begin{array}{ll}\text { - } & \text { drum } \\ \text { - } & \text { corrosion } \\ \text { - } & \text { rust } \\ \text { - } & \text { failure } \\ \text { - litigation } \\ \text { - liability } \\ \text { - waste } \\ \text { - inspection } \\ \text { - } \text { refurbishment. }\end{array}$

Other search topics included

- $\quad$ high integrity containers

- polyethylene encapsulates for hazardous waste drums

- $\quad$ nondestructive testing of waste drum integrity

- corrosion tests for low-level radioactive waste drum containers

- alternative building materials/materials selection for 55-gallon drums

- reactions of steel with waste material in 55-gal drums

- $\quad$ case studies of corrosion of mixed waste and transuranic waste containers.

There are innumerable texts and articles written on corrosion. A detailed study into rust and corrosion is beyond the scope of this report. There are many related publications, but only one article, by S.T. Kosiewicz of Los Alamos National Laboratory, 1988, contained information specifically on internal corrosion of 55-gal steel storage drums by waste streams. A summary of applicable literature will be included in the year-end project report, due in September, 1995.

\subsection{Idaho National Engineering Laboratory}

The initial search began on the INEL within the Waste Reduction Operations Complex (WROC) Technical Programs working group. The MWSF, where the mercury sludge problem surfaced, is one of the facilities managed by WROC. This group has a waste generator interface team that interfaces with INEL facilities and other sites that ship waste to the MWSF. They have first-hand knowledge of all of 
the drums that have been overpacked in the MWSF over the last several years due to internal corrosion. Although the MWSF had the most immediate corrosion impacts, the INEL's Radioactive Waste Management Complex (RWMC) has the largest number of drums in storage and offers the greatest potential for $\mathrm{P}^{2}$ opportunities. The study was therefore extended to the RWMC.

\subsection{DOE Complex-Wide Search}

The project was then extended across the whole DOE complex. A telephone survey was conducted to locate the person(s) responsible for and having data on these waste streams. After the survey was developed, a packet of survey material was sent out to each person on the contact list. At some sites more than one contact person was contacted. The survey material contained the following documents:

- $\quad$ an introductory letter about the study

- the background information about the study

- the instructions for the survey work sheets

- $\quad$ the survey work sheets

- $\quad$ a survey work sheet sample to be used as a guide.

See Appendix A for copies of the survey packet material.

Each person was contacted one week after the surveys were mailed to ensure he/she received it. After the survey was received one of the following actions ensued:

- completed by the contact

- $\quad$ passed on to another to complete

- given to another who had the information

- held by the contact (no action).

The contact list was changed frequently because the survey was typically passed from the initial recipient to another person except for the five contacts that held the survey and performed no action. A telephone conversation log (dates and content notes) was created for each contact to ensure contact and record verbal communications.

\subsection{Hypothesis}

The complex wide survey was based on the hypothesis that drums fail principally from internal corrosion as a function of waste stream. 


\subsubsection{Failure by Corrosion}

Figure 1-1 shows a schematic of the two principal modes of drum corrosion failure: a) pitting corrosion, and b) general corrosion. Figure 1-2 shows the hypothetical corrosion depth, $x(t)$, as a function of time. There is no scale on the time axis since neither the corrosion rate, $\mathrm{dx} / \mathrm{dt}$, nor the time to failure, $t_{f}$, is known. The survey set out to identify the waste streams (WS) that are especially corrosive to steel waste drums and the time to earliest failure for each waste stream for which drums have been observed to fail by corrosion.

The three curves in Figure 1-2 depict linear corrosion (curve 1), corrosion which is initially slow but increases with time (curve 2), and corrosion which is initially rapid and slows asymptotically (curve 3). All physical corrosion curves must show corrosion depth as a monotonically increasing function (the corroding container wall can not heal itself), i.e., $\mathrm{dx} / \mathrm{dt} \geq 0$. Failure will occur when the corrosion depth is equal to the container wall thickness, $x_{c w}$, i.e., when $x(t)=x_{c w}$.

Since $x(t)$ must increase in time, for a given waste stream, $\mathrm{WS}_{\mathrm{i}}$, the number of failures of containers holding the $\mathrm{i}^{\text {th }}$ waste stream, $\mathrm{n}_{\mathrm{i}}$, is also expected to increase with time. However, since the population of drums within any waste stream is finite, $\mathrm{dn}_{\mathrm{i}} / \mathrm{dt}$ must eventually decrease as the population of drums of the $\mathrm{i}^{\text {th }}$ waste stream is depleted. Since this survey did not request either the individual waste stream drum population or the number of drums failed as a function of time, no correlation could be made with this portion of the theory.

The principal governing parameters of corrosion for a given material are $\mathrm{pH}$, presence of oxygen or an oxidizer, transport mechanism (generally water, often a function of relative humidity), the presence of surface films (either protective or destructive), and temperature. A corrosive waste stream will be one which provides a high or low $\mathrm{pH}$, oxidizer, and transport mechanism conducive to corrosion.

The severity of corrosion can be measured by the time-to-failure. The shorter the time-to-failure, the more corrosive the waste stream.

\subsubsection{Internal versus External Corrosion}

Waste drums may fail either by corrosion which originates and propagates from the inside of the container out (internal corrosion) or from the outside of the container in (external corrosion).

External corrosion is essentially independent of waste stream. Furthermore, based on the discussion below, failure by external corrosion is not expected to occur under conditions of indoor storage for 20 years. Drum exteriors are generally painted or galvanized. These protective films will resist or retard corrosion until they themselves degrade significantly or have been mechanically rendered ineffective. External corrosion of carbon steel drums is dependent on the availability of moisture and the presence of air pollutants which promote corrosion. Thus, for dry storage conditions, the corrosion rate is very low. 


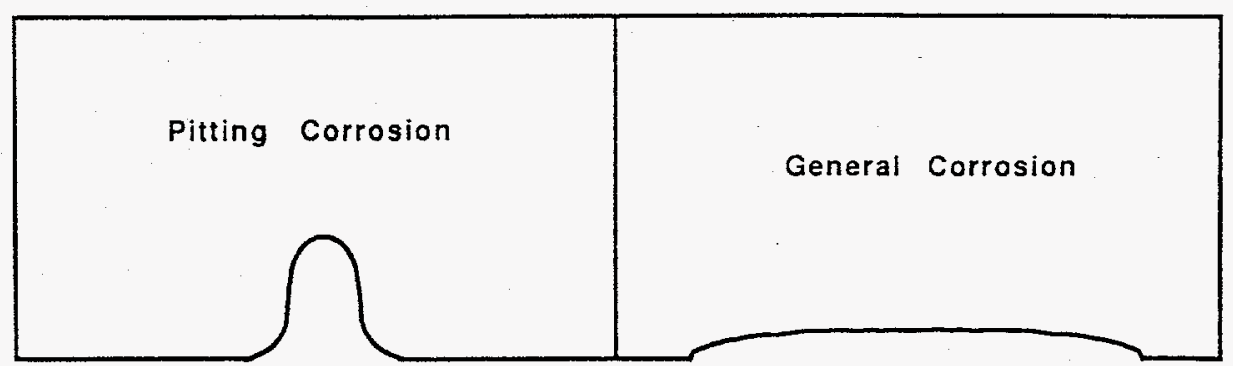

Pitting corrosion: Pitting corrosion is at General corrosion: Surface layers of metal distinct spots where deep pits are produced. The pit acts as a small corrosion cell. are converted to corrosion products in such Pitting rate will be about ten times the a way that the thickness of the section is uniformly decreased. general rate of corrosion.

Figure 1-1. Drum Corrosion Types.

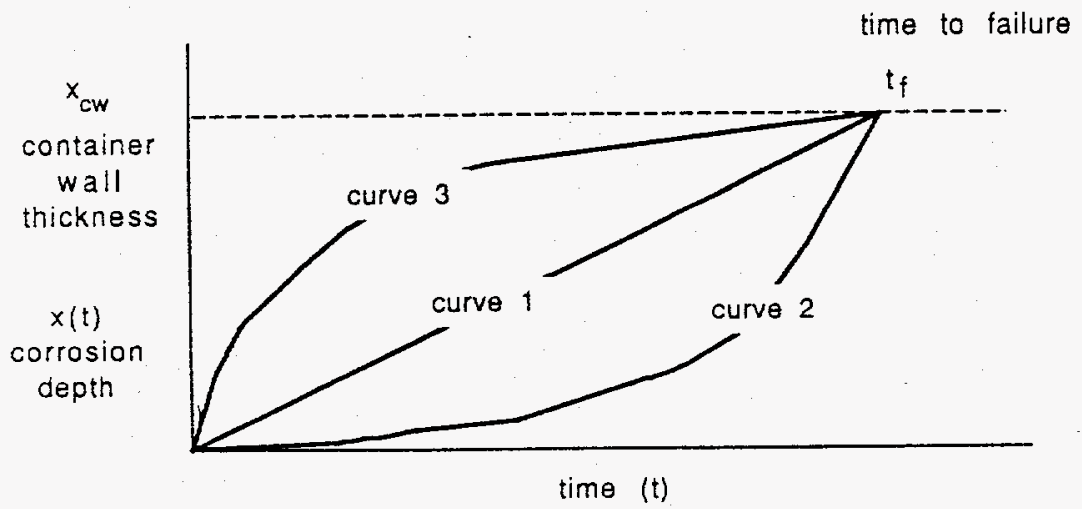

Curve 1: linear corrosion rate

Curve 2: Corrosion which is initially slow but increases with time

Curve 3: corrosion which is initially rapid and slows asymtoptically decreasing with time

Figure 1-2. Corrosion Curves. 
In Figure 3, a time scale has placed on the curve, which is a composite of curves 1 and 3 from Figure 1-2. At the RWMC, drums have been in a weather protected but otherwise limited control environment for up to 12 years. None of these drums have experienced internal corrosion failure; approximately $1 \%$ either have been overpacked or will shortly be overpacked due to visibly severe external corrosion. This is inconsistent with the original design life of 20 years. Under good conditions, drums could be expected to last 20 to 40 years. Sometime beyond 40 years most will have failed or be near failure.

Based on a nominal corrosion rate of carbon steel of about $0.001 \mathrm{in} / \mathrm{yr}$ ( $25 \mathrm{micron} / \mathrm{yr}$ ) and a drum wall thickness of 0.06 in., the 20 - 40 years expected life corresponds to a loss of $30 \%$ to $50 \%$ wall thickness. A general corrosion rate of 0.01 to 0.02 in./yr is generally listed as "moderate" corrosion. Pitting corrosion is generally ten times as rapid as general corrosion; internal corrosion is expected to be dominated by pitting corrosion. For a 55-gal drum, such a corrosion rate would coincide with an early time-to-failure of 2-5 years.

Based on the model shown in Figure 3 and the fact that highly corrosive wastes were rarely packed directly in carbon steel drums, we anticipate that there will be an early failure peak of 2-5 years attributable to internal corrosion. Very few, if any, drums have been stored in protected, inspectable storage for times required to experience significant failures by external corrosion. 


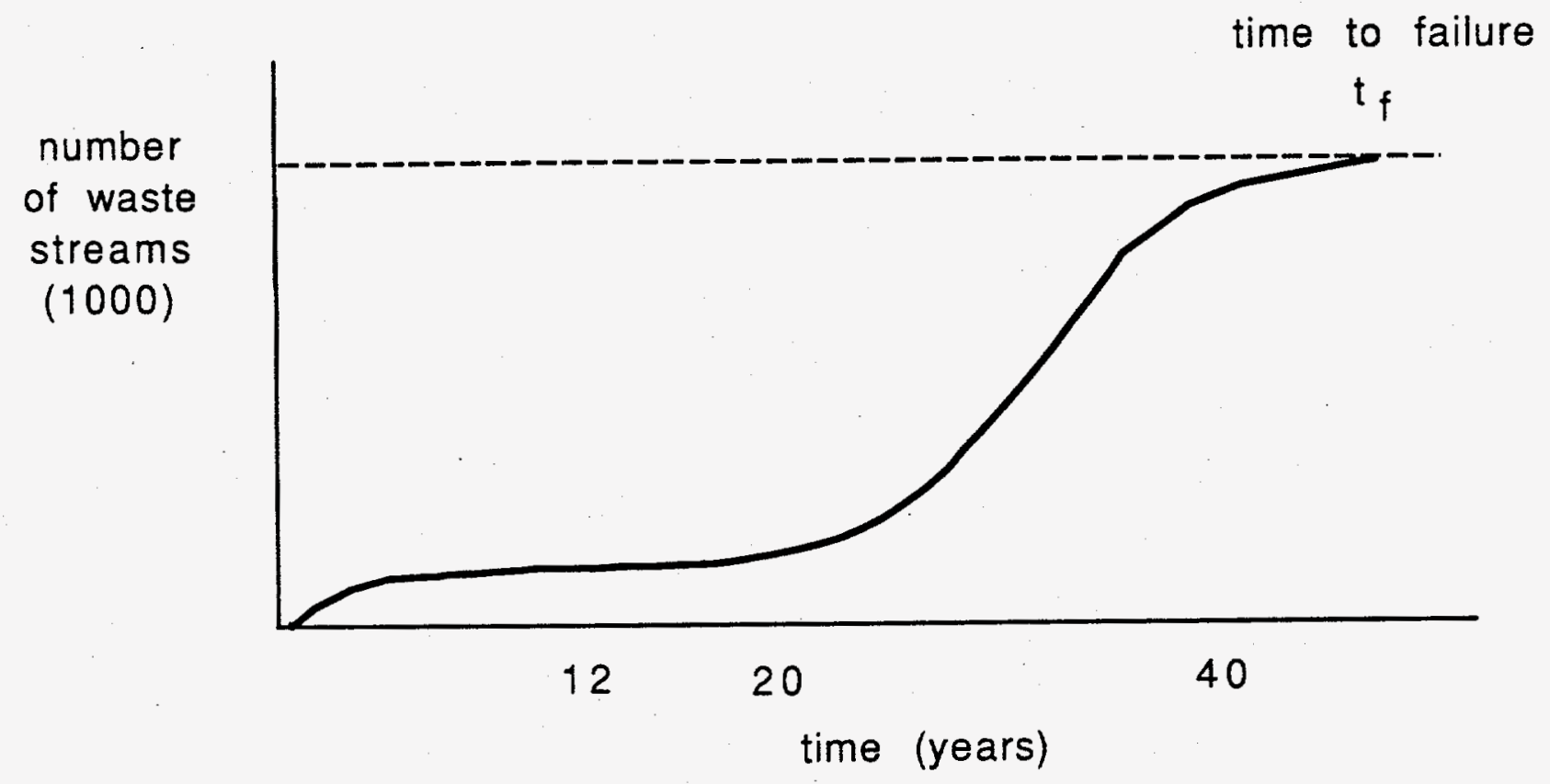

Figure 2. Expected Drum Failure Rates. 


\section{DATA ACQUISITION}

As each site contact was consulted, it became apparent that each contact had different priorities of work and willingness to participate in the survey. To some, it was no problem to furnish the data; others required permission from their DOE counterpart, and several did not participate. Appendices B and C list the survey responses. After the initial formal request for the information, periodic telephone calls were used to request the information. There were three typical responses to the survey. The respondents

- believed no problem exists (internal drum corrosion is not a problem to this site)

- $\quad$ cooperated by completing and returning survey work sheets

- gave no response (not able or willing to supply the data).

As data were received from facility and site contacts, it was transcribed into "Work Sheet Tables" for each contact. 


\section{RESULTS}

Twenty-one contacts were made throughout the INEL and DOE facilities. Five of the contacts responded that their site did not have a drum corrosion problem or had not yet observed it. Five contacts at three sites, Mound, Fernald, and Oak Ridge, did not respond to the survey. Of the five, two refused to assist or had no comment. Two contacts waited three months for DOE counterpart permission, but did not respond, and one promised to respond but was unable to respond at the time of this report.

Six sites responded to the survey; their information is listed in Appendix D. They identified a total of 21 waste streams that have corroded the original 55-gal storage drums which had to be overpacked or repackaged. The number of failed drums within each waste stream was not requested. Also, the total number of waste streams was not identified; although on the INEL, there are in excess of 1,000 different waste streams. The 21 waste streams are listed in a composite list shown in Appendix D. These waste streams can be placed into four groups:

- $\quad$ acids (5 waste streams)

- $\quad$ salts/halogens (2 waste streams)

- $\quad$ solvents/still bottom sludges ( 8 waste streams)

- $\quad$ miscellaneous (6 waste streams).

The acid waste streams were those used in cleaning parts, equipment, or piping. The acids used included nitric, hydrochloric, and citric. The salt components included nitrates, nitrites, and sulfates. The solvents included 1.1.1-trichloroethane (TCA), carbon tetrachloride, and paint stripper. The miscellaneous waste stream components included rain water, oil/grease, freon-113, fly ash, soils, and blasting grit.

The number of drums for each waste stream was not identified during this survey. Each waste stream could have from one to hundreds of drums. Figure 3 shows the time to failure for the first drum of a each specific waste stream to fail. Most of the waste streams experienced failures within three years; the longest time to first failure was seven years. This observation is in agreement with Figure 2 and supports our hypothesis that the failures are due to internal corrosion. 


\section{Drum Failures}

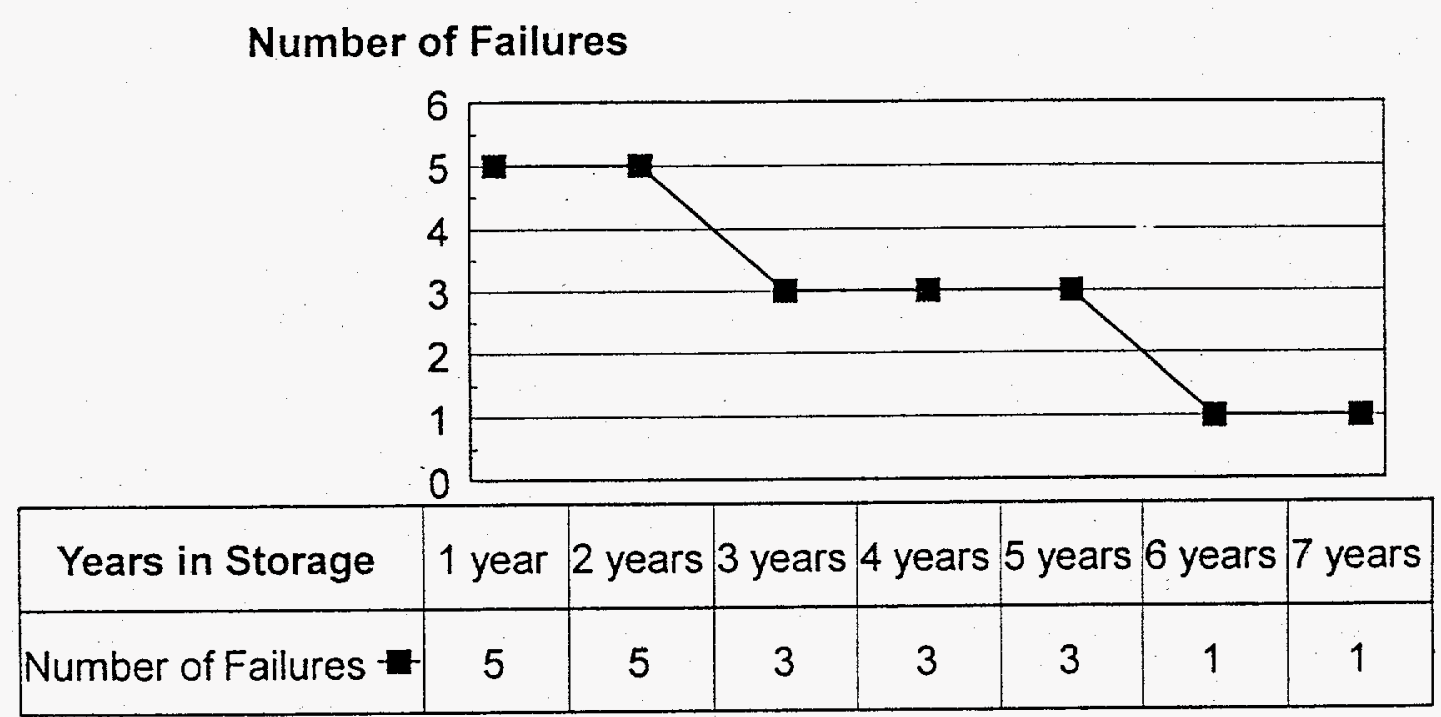

The survey reported that 21 waste streams from seven DOE facilities caused the 55-gal steel storage drums to be overpacked or repackaged because of preferential corrosion by the waste stream componants on the drum.

Figure 3. Drum Failures. 


\section{RECOMMENDATIONS AND CONCLUSIONS}

\subsection{Recommendations}

It is recommended that the composite list of waste streams be furnished to those who generate, package or ship radioactive wastes to give them a "heads-up" if and when they package similar waste streams. The use of a polyethylene (poly) drum, a poly liner with a drum, a poly-lined drum, or some other protection to the drum is advised. The awareness of these waste streams will support the pollution prevention and waste minimization philosophy of waste elimination on the front end of a process.

An early container failure is evidence of a corrosive waste stream. All other containers in that particular waste stream should be judged to be at risk for corrosion failure. The drums should be placed under special surveillance. Further action to avoid failure and loss of containment may be based on a more in-depth evaluation of that waste stream and its packaging.

Recommendations for future work and a more complete and in depth study would include:

R1. Obtain complete complex wide data.

R2. Have DOE-HQ request data from the individual operations to ensure cooperation finding waste streams that have been overpacked or repackaged due to internal corrosion.

R3. Identify the number (quantity) of drums at risk and the number failed.

R4. Fund each site for its efforts to ensure better participation

R5. Include results on the World Wide Web or one of the many established DOE information sharing programs.

R6. With the small number of drums that failed from interior corrosion, investigate exterior corrosion because it is greater potential for pollution prevention.

\subsection{Conclusion}

It must be noted that many of the today's problems stem from yesterday's actions. The best management practice of years ago may now be unacceptable or illegal. The short time to failure of some waste streams, discovered as the results of this study, were not unexpected, but the composite list will provide additional bases to guide the packaging of waste to avoid corrosion, and thus, to minimize waste generation by minimizing the need to overpack failed drums. The study at this point supports the following conclusion.

- $\quad$ Containers with corrosive waste streams fail early (within 7 years).

- Waste streams with acids require added measures to protect the steel storage drum. 
- Waste streams that have solvent liquids, sludge, and still bottoms should use added measures to protect the steel storage drum.

- Many recently packaged waste streams were packaged into non-compatible drums.

- The synergistic effect between the component parts of the waste and the drum are not intuitively obvious; therefore, when dealing with border-line compatibility waste streams, poly liners or drums are advisable. 


\section{Appendix A \\ Survey Packet}

A-1 
•

, 
February 9,1995

(contact person site name and address)

\section{DRUM REFURBISHMENT STUDY}

Dear (site contact):

The Department of Energy (DOE) Office of Waste Minimization (EM-334) is funding the Idaho National Engineering Laboratory to perform corrosion, material optimization and refurbishment studies of 55-gallon steel drums used to store hazardous and radioactive waste.

This effort includes the collection of existing corrosion data such as rust types, patterns on drums, and waste streams that corrode the storage drums. In an effort to provide useful results to EM-334, and the rest of the DOE complex, your participation is requested. Your input will be included in a DOE complex wide report and will meet a DOE-HQ milestone this spring.

Enclosed is a work sheet used to identify waste streams at the INEL site which selectively corrode steel drums (Enclosure 3). Please fill out the enclosed form according to the instructions (Enclosure 1 and 2). An example of a filled out work sheet and background information are included (Enclosure 4).

I look forward to working with you on this project. If you have any questions, please contact Curtis Reece at (208) 526-6490, or Larry Zirker at (208) 526-3339.

Sincerely,

L.E. Ewing, Acting Manager

WROC Technical Programs

LRZ:ps

Enclosures:

1. Background and Instructions

2. Instructions for Completing the Waste Stream Corrosion Work sheet

3. Work sheet for Waste Streams Which Preferentially Corrode Steel Drums

4. Example of Work sheet for Waste Streams Which Preferentially Corrode Steel Drums

cc: G.A. Beitel, LITCO, MS 8102

G.E. Ellis, LITCO, MS 3940

C.P. Ischay, LITCO, MS 2420

G.L. Schwendiman, LITCO, MS 8102

R.A. Taft, DOE-ID, MS 4160

M.C. Tiernan, LITCO, MS 8101

J.A. Van Vliet, LITCO, MS 3940

L.R. Zirker, LITCO, MS 8101

L.E. Ewing File 


\section{BACKGROUND AND INSTRUCTIONS}

Thousands of 55-gallon drums, DOE complex wide, are used to store hazardous and radioactive wastes. Different sites have their own storage facilities and storage conditions; many containers are in various stages of deterioration from corrosion. Standard 55-gallon steel drums are designed to transportation specifications, not for long term storage. It is a standard practice when a waste storage drum fails in service, to either overpack the drum or repackage the waste. Studies performed at the Idaho National Engineering Laboratory (INEL) demonstrate the ultimate cost to over-pack a 55-gal drum is approximately $\$ 1500.00$ for mixed-low level waste; this includes the new drum, handling, storage, transportation and disposal costs.

Little is known about the preferential corrosion by waste streams on steel drums. The INEL seeks to identify waste streams that demonstrate deleterious (preferential corrosion) effects on the storage life of 55-gal drums. We are looking to identify these waste streams, at the DOE sites, that have caused the original 55-gal steel storage drums to fail (corrode, breach or leak) in service and be either repackaged or over packaged. This is an attempt to establish a relationship between waste drum failure and waste type. In a recent INEL study, waste streams that demonstrated deleterious effects and drum failure were identified. This list fills two purposes 1 . It will a provide a "heads-up" notice of waste streams which promote premature drum failure to waste generators and waste generator interface's on drum material selection for these waste streams. 2. It will aid the DOE waste Minimization and pollution prevention efforts by eliminating, on the front end of a process, waste, pollution and extra costs associated with over-packing or repackaging.

We seek information on 55-gal steel drums used to store transuranic, mixed or low-level alpha containing wastes; other containers need not be addressed. The criteria to be used to determine that the drum has failed shall be that action has been taken to either over pack the original drum or repackage the original waste. Drums known to have failed by a mechanism other than corrosion (handling storage) shall not be considered. For each drum that has failed in service due to corrosion, please provide available information on waste contents. If a content code is used, also provide the interpretation of that code. To assist you in completing this task, a work-sheet, with directions, will be supplied to you along with an example of a completed worksheet performed at the INEL. The data from each site will be compiled into a complex wide report.

This report will be proposed by the Waste Reduction Operations Complex at the INEL to meet a DOE-HQ Milestone. Also a final report will be dispersed to all sites within the complex for their own use and information. Please query your waste container data base system or provide this information related to drum failure and waste contents. Please reply by March 1, 1995. For technical details or further information contact Larry Zirker of the INEL at 208-526-3339. 


\section{Instructions for Work Sheets}

1. Name of site: Write in the name of the site. Spell out the site name and include the abbreviation.

2. Contractor: Name of the contractor.

3. Name: Write in the name of the person who has prepared this form.

4. Mailing Address: Write in mailing address and mail stop.

5. Telephone Number: Write complete telephone number.

6. Fax Number: Write complete fax number.

7. Other responsible parties: Write in the name of other people who may be involved with identifying the waste streams corroding steel drums.

8. Facility: Write in the name of the facility which the waste was stored prior to failure.

9. Bar Code: Bar code number used to track the drum (N/A if none).

10. Waste Stream I.E. number: Site ID number used to identify waste stream (N/A if none).

11. Waste Type (use the following categories): Use this two (2) letter code.

- hazardous (HW) - industrial (IN) - low level (LL)

- sanitary (SA)

- transuranic (TR) - TSCA (TS) $\quad$ - transuranic mixed (TM)

- low-levelmixed(LM) - high level (HL) - Unknown (UN)

12. Waste State: Physical state of the waste. Use the (1) letter code.

- Solid (S)

- Gas (G)

- Liquid (L) -Multiphase/liquid/solid(M)

- Unknown (U)

13. Description of the waste: Brief description of the waste. If codes are used, interpret code.

14. Process generating the waste: Briefly describe the process which generates the waste.

15. Time in storage: Number of years in storage.

16. Material type of original drum: Painted carbon steel, galvanized carbon steel, stainless steel, polyethylene, other.

17. Type of Over pack or Repack: Container used to maintain packaging of the waste (55-gal steel, 83-gal polyethylene, etc).

18. Time to failure: Years of storage before drum corrosion was noticed. For additional questions, contact Larry Zirker at (208) 526-3339, or Curtis Reece at (208) 526-6490. 
Work Sheet for Waste Streams

Name of site:

Contractor :

Name:

Mailing Address:

Telephone Number:

Fax Number:

Other responsible parties:

\begin{tabular}{|c|c|c|c|c|c|c|c|c|c|}
\hline \multicolumn{4}{|c|}{ Facility: } & \multicolumn{6}{|c|}{ SHEET ___ OF } \\
\hline $\begin{array}{c}\text { BAR } \\
\text { CODE }\end{array}$ & $\begin{array}{l}\text { WASTE } \\
\text { STREAM } \\
\text { I.E. } \\
\text { NUMBER }\end{array}$ & $\begin{array}{l}\text { WASTE } \\
\text { TYPE }\end{array}$ & $\begin{array}{l}\text { WASTE } \\
\text { STATE }\end{array}$ & $\begin{array}{l}\text { DESCRIPTION OF THE } \\
\text { WASTE: }\end{array}$ & $\begin{array}{l}\text { PROCESS GENERATING } \\
\text { THE WASTE }\end{array}$ & $\begin{array}{c}\text { TIME IN } \\
\text { STORAGE } \\
\text { (years) }\end{array}$ & $\begin{array}{l}\text { MATERIAL } \\
\text { TYPE OF } \\
\text { ORIGINAL } \\
\text { DRUM }\end{array}$ & $\begin{array}{c}\text { TYPE OF } \\
\text { OVER PACK } \\
\text { OR REPACK }\end{array}$ & $\begin{array}{c}\text { TIME TO } \\
\text { FAILURE } \\
\text { (Years) }\end{array}$ \\
\hline & & & & & & & & & \\
\hline & & & & & & & & & \\
\hline & & & & & & & & & \\
\hline & & & & & & & & & \\
\hline
\end{tabular}




\section{Page 2 of Work Sheet for Waste Streams}

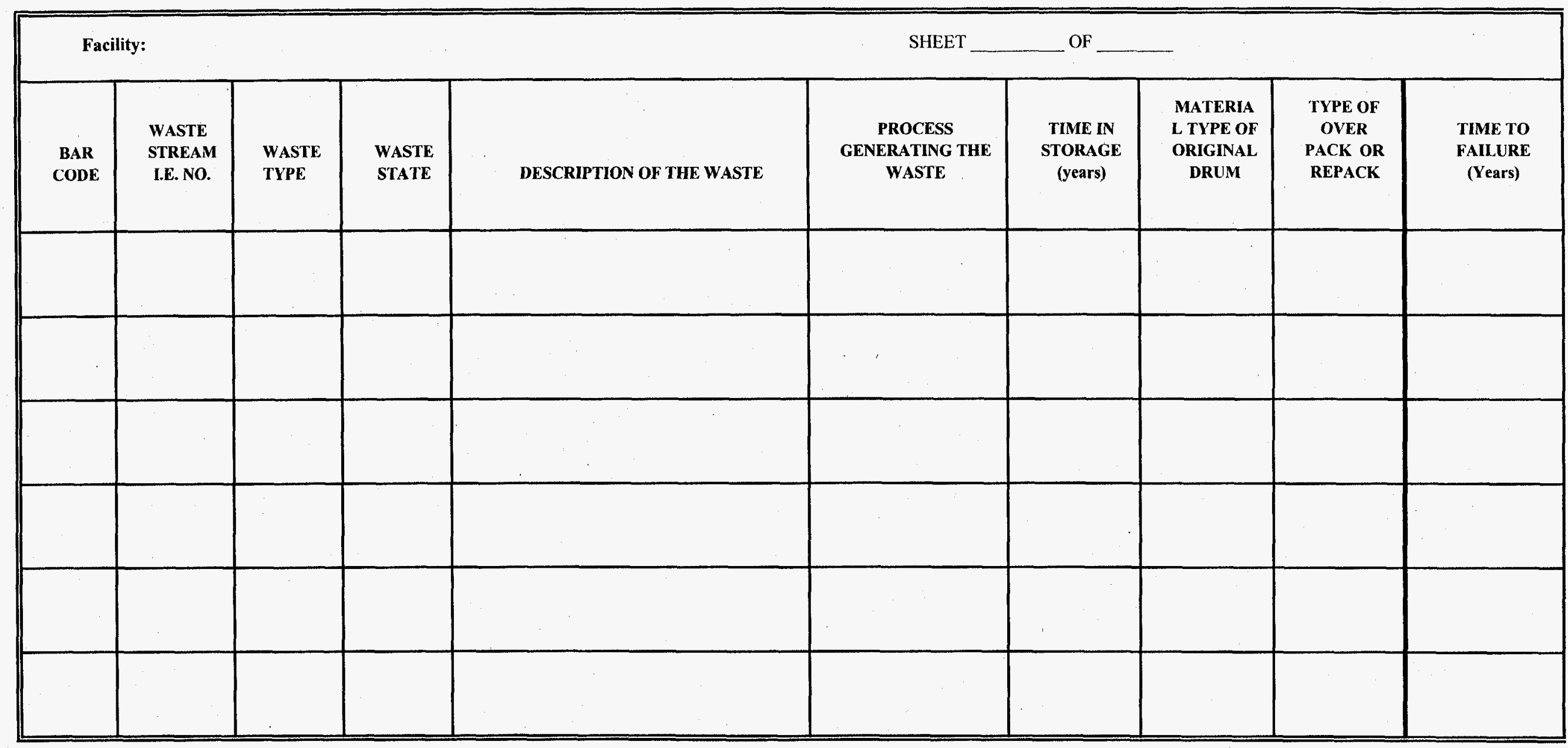




\section{Example of Work Sheet}

\section{Work Sheet for Waste Streams Which Preferentially Corrode Steel Drums}

Name of site: Idaho National Engineering Laboratory (INEL)

Contractor : Lockheed Idaho Technologies Company (LITCO)

Name: Larry Zirker Mailing Address: P.O. Box 1625, Idaho Falls, ID 83415-8101

Telephone Number:(208) 526-3339 Fax Number: (208) 526-6933

Other responsible parties: Curtis Reece, (208) 526-6490

\begin{tabular}{|c|c|c|c|c|c|c|c|c|c|}
\hline \multicolumn{7}{|c|}{ Facility: Mixed Waste Storage Facility } & \multicolumn{3}{|c|}{ SHEET 1 OF 1} \\
\hline $\begin{array}{c}\text { BAR } \\
\text { CODE }\end{array}$ & $\begin{array}{l}\text { WASTE } \\
\text { STREAM } \\
\text { I.E. } \\
\text { NUMBER }\end{array}$ & $\begin{array}{l}\text { WASTE } \\
\text { TYPE }\end{array}$ & $\begin{array}{l}\text { WASTE } \\
\text { STATE }\end{array}$ & $\begin{array}{l}\text { DESCRIPTION OF THE } \\
\text { WASTE: }\end{array}$ & $\begin{array}{c}\text { PROCESS } \\
\text { GENERATING THE } \\
\text { WASTE }\end{array}$ & $\begin{array}{c}\text { TIME IN } \\
\text { STORAGE } \\
\text { (years) }\end{array}$ & $\begin{array}{c}\text { MATERIAL } \\
\text { TYPE OF } \\
\text { ORIGINAL } \\
\text { DRUM }\end{array}$ & $\begin{array}{l}\text { TYPE OF } \\
\text { OVER PACK } \\
\text { OR REPACK }\end{array}$ & $\begin{array}{c}\text { TIME TO } \\
\text { FAILURE } \\
\text { (Years) }\end{array}$ \\
\hline $\begin{array}{l}\text { INEL } \\
686\end{array}$ & 997 & LL & $\begin{array}{l}\text { Liquid/ } \\
\text { Sludge }\end{array}$ & Mercury Contaminated Concrete & $\begin{array}{l}\text { Rinsing HTRE with } \\
\text { nitric acid to remove } \\
\text { mercury }\end{array}$ & 7 & steel & 83-gal poly. & 3 \\
\hline $\begin{array}{l}\text { INEL } \\
686\end{array}$ & 1006 & LL & Solid & Solidified fly ash & $\begin{array}{l}\text { Stabilization } \\
\text { development }\end{array}$ & 8 & steel & 83-gal poly. & 4 \\
\hline
\end{tabular}




\section{Appendix B}

INEL Survey Contacts and Responses

B-1 
. 
INEL Contacts and Survey Response

\begin{tabular}{||l|l||}
\hline \multicolumn{2}{|c|}{ INEL DRUM CORROSION CONTACTS } \\
\hline \multicolumn{1}{|c|}{ AREA } & \multicolumn{1}{c|}{ COMMENTS } \\
\hline Argonne National Laboratory--West & No corrosion from inside out \\
\hline Decontamination and Decommissioning & No corrosion from inside out \\
\hline Idaho Chemical Processing Plant & No response to the survey \\
\hline Navel Reactor Facility & No corrosion from inside out \\
\hline $\begin{array}{l}\text { Test Area North and Specific } \\
\text { Manufacturing Capability }\end{array}$ & See composite list \\
\hline Test Reactor Area & See composite list \\
\hline $\begin{array}{l}\text { Waste Reduction Operations Complex } \\
\text { (WROC) }\end{array}$ & See composite list \\
\hline
\end{tabular}


Appendix C

DOE Contact and Survey Response 
C-2 
DOE Contacts and Survey Response

\begin{tabular}{||l|l||}
\hline \multicolumn{1}{|c||}{ DOE SITE DRUM CORROSION CONTACTS } \\
\hline AREA & \multicolumn{1}{|c||}{ COMMENTS } \\
\hline $\begin{array}{l}\text { Fernald Environmental Restoration } \\
\text { Management Company }\end{array}$ & No response to the survey \\
\hline Los Alamos National Laboratory & See composite list \\
\hline Mound & No response to the survey \\
\hline Nevada Test Site & No corrosion from inside out \\
\hline Oak Ridge National Laboratory & No response to the survey \\
\hline Rocky Flats Plant & See attached work sheet \\
\hline West Valley Nuclear Site & No corrosion from inside out \\
\hline Westinghouse Hanford Company & See composite list \\
\hline Westinghouse Savannah River Site & See composite list \\
\hline
\end{tabular}




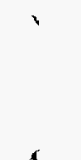




\section{Appendix D}

Composite List of Waste Streams Identified Which Preferentially Corrode 55-Gal Steel Drums 
D-2 


\section{Composite List of Waste Streams Identified Which Preferentially Corrode 55-Gal Steel Drums}

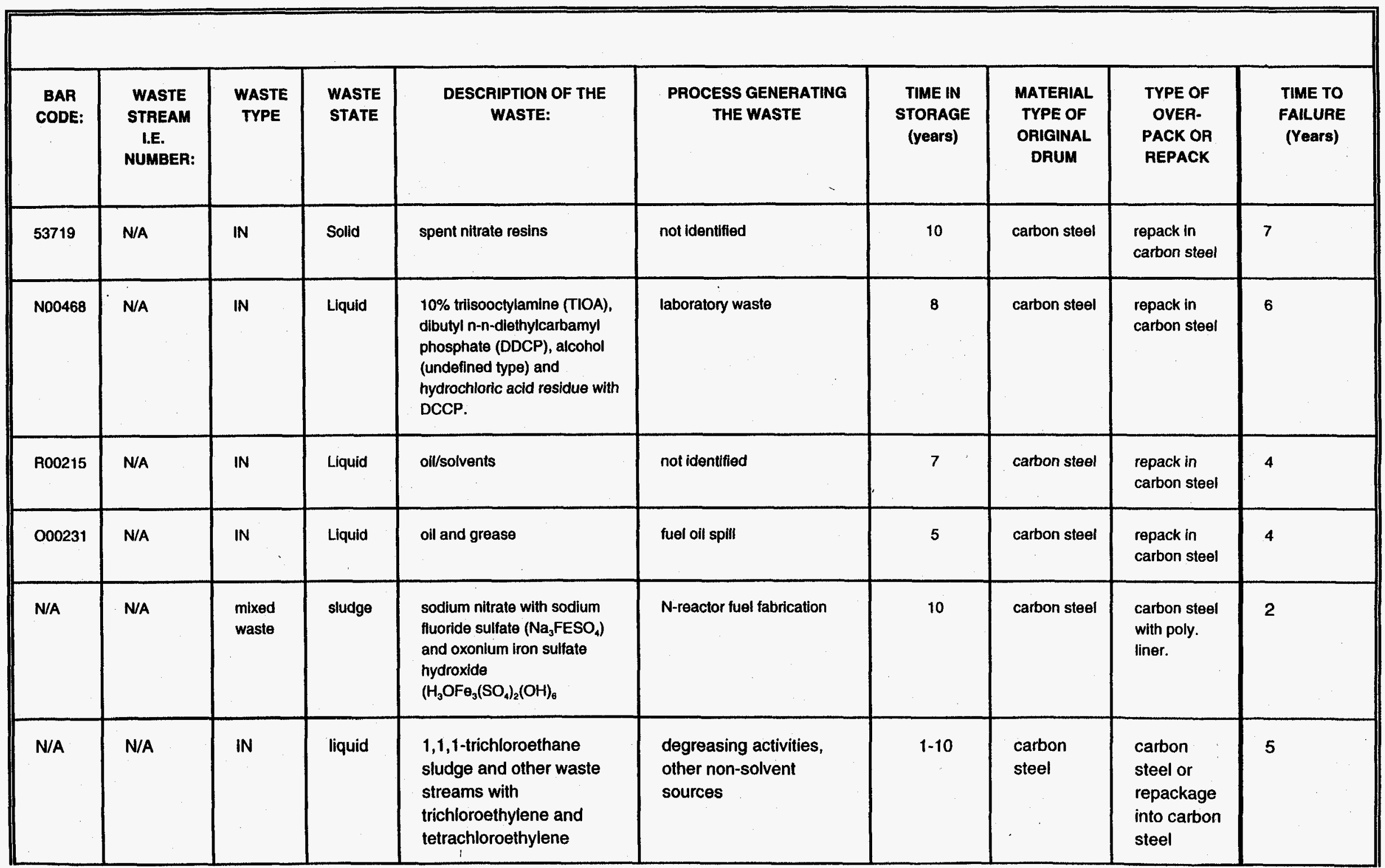




\begin{tabular}{|c|c|c|c|c|c|c|c|c|c|}
\hline N/A & $\begin{array}{l}\text { HWSF } \\
\text { LOG \#1- } \\
331\end{array}$ & HAZ. & liquid & $\begin{array}{l}\text { halogenated and non- } \\
\text { halogenated contaminated } \\
\text { water (solvents approx. } \\
100 \mathrm{ppm} \text { ). }\end{array}$ & site remediation activities. & $5-10$ & $\begin{array}{l}\text { carbon } \\
\text { steel }\end{array}$ & $\begin{array}{l}\text { carbon } \\
\text { steel or } \\
\text { repackage } \\
\text { into carbon } \\
\text { steel }\end{array}$ & 2 \\
\hline N/A & $\mathrm{N} / \mathrm{A}$ & IN & liquid & $\begin{array}{l}\text { abrasive blasting grit (with } \\
\text { water in it) }\end{array}$ & $\begin{array}{l}\text { site construction } \\
\text { activities }\end{array}$ & $1-5$ & $\begin{array}{l}\text { carbon } \\
\text { steel }\end{array}$ & $\begin{array}{l}\text { carbon } \\
\text { steel }\end{array}$ & $<1$ \\
\hline N/A & M3-41 & IN & liquid & spent freon-113 & degreasing activities & 5 & $\begin{array}{l}\text { carbon } \\
\text { steel }\end{array}$ & $\begin{array}{l}\text { carbon } \\
\text { steel }\end{array}$ & 5 \\
\hline$N / A$ & M3-119 & IN & liquid & $\begin{array}{l}\text { dilute nitric acid }(\mathrm{pH} 4) \\
\text { with mercury }\end{array}$ & tank clean out & 3 & $\begin{array}{l}\text { carbon } \\
\text { steel }\end{array}$ & $\begin{array}{l}\text { carbon } \\
\text { steel }\end{array}$ & 3 \\
\hline$N / A$ & N/A & $\mathrm{LL}$ & liquid & $\begin{array}{l}\text { Bulked TCA }(1,1,1- \\
\text { trichloroethane) still } \\
\text { bottoms }\end{array}$ & $\begin{array}{l}\text { material leftover from } \\
\text { recycle of used TCA }\end{array}$ & 2 & steel & $\begin{array}{l}83 \text { gal. } \\
\text { poly } \\
\text { overpack }\end{array}$ & 1 \\
\hline N/A & $N / A$ & LL & liquid & Bulked TCA still bottoms & $\begin{array}{l}\text { material leftover from } \\
\text { recycled TCA }\end{array}$ & 3 & steel & $\begin{array}{l}\text { 55-gal. } \\
\text { poly lined } \\
\text { drum }\end{array}$ & 1 \\
\hline N/A & N/A & LL & liquid & Bulked TCA still bottoms & $\begin{array}{l}\text { material leftover from } \\
\text { recycled TCA }\end{array}$ & 3 & steel & $\begin{array}{l}55 \text { gal. } \\
\text { poly drum }\end{array}$ & 1 \\
\hline$N / A$ & $N / A$ & $\mathbb{I N}$ & liquid & $\begin{array}{l}\text { citric acid based cleaning } \\
\text { solution }\end{array}$ & $\begin{array}{l}\text { cleaning secondary side } \\
\text { of a heat exchanger }\end{array}$ & 3 & $\begin{array}{l}55-\text { gal } \\
\text { poly. }\end{array}$ & $\begin{array}{l}\text { repacked } \\
\text { into blue } \\
\text { poly drums }\end{array}$ & 3 \\
\hline$N / A$ & A75 & TR & $\mathrm{s}$ & $\begin{array}{l}\text { cemented TRU sludge } \\
\text { waste form. }\end{array}$ & $\begin{array}{l}\text { residue and evaporation } \\
\text { distillate are immobilized } \\
\text { in cement }\end{array}$ & 15 & steel & $\begin{array}{l}85-g a l \\
\text { steel }\end{array}$ & 2 \\
\hline$N / A$ & A14 & TR/LL & $\mathrm{s}$ & paint stripper on rags & paint stripping & 13 & steel & $\begin{array}{l}85-g a l \\
\text { steel }\end{array}$ & 2 \\
\hline
\end{tabular}




\begin{tabular}{|c|c|c|c|c|c|c|c|c|c|}
\hline N/A & LLA36 & LL & $\mathbf{s}$ & $\begin{array}{l}\text { mixed low level waste: } \\
\text { lead contaminated soils }\end{array}$ & $\begin{array}{l}\text { lead contaminated soils } \\
\text { from D\&D }\end{array}$ & 13 & steel & $\begin{array}{l}\text { 85-gal } \\
\text { steel }\end{array}$ & $1-2$ \\
\hline $\begin{array}{l}\text { INEL } \\
686\end{array}$ & 997 & LL & LS & $\begin{array}{l}\text { mercury contaminated } \\
\text { concrete }\end{array}$ & $\begin{array}{l}\text { rinsing HTRE with nitric } \\
\text { acid to remove mercury }\end{array}$ & 7 & steel & 83-gal poly & 3 \\
\hline N/A & 1006 & LL & $s$ & solidified fly ash & stabilization development & 8 & steel & 83-gal poly & 4 \\
\hline$N / A$ & N/A & TRU & $L$ & carbon tetrachloride & plutonium reclamation & 2 & steel & $\begin{array}{l}\text { 55-gal with } \\
\text { liner }\end{array}$ & 0.5 \\
\hline N/A & N/A & $N / A$ & liquid & $\begin{array}{l}\text { rainwater entering TRU } \\
\text { waste drums. }\end{array}$ & $\begin{array}{l}\text { diurnal temperature } \\
\text { cycling }\end{array}$ & 9 & $\begin{array}{l}\text { carbon } \\
\text { steel }\end{array}$ & $\begin{array}{l}\text { repack in } \\
\text { carbon } \\
\text { steel } \\
\text { drums after } \\
\text { de- } \\
\text { watering }\end{array}$ & 4.5 \\
\hline
\end{tabular}

